\title{
Hypoxia-ischemia and retinal ganglion cell damage
}

\author{
Charanjit Kaur' \\ Wallace S Foulds ${ }^{2}$ \\ Eng-Ang Ling' \\ 'Department of Anatomy, Yong Loo \\ Lin School of Medicine, National \\ University of Singapore, Singapore; \\ ${ }^{2}$ Singapore Eye Research Institute, \\ Singapore
}

\begin{abstract}
Retinal hypoxia is the potentially blinding mechanism underlying a number of sight-threatening disorders including central retinal artery occlusion, ischemic central retinal vein thrombosis, complications of diabetic eye disease and some types of glaucoma. Hypoxia is implicated in loss of retinal ganglion cells (RGCs) occurring in such conditions. RGC death occurs by apoptosis or necrosis. Hypoxia-ischemia induces the expression of hypoxia inducible factor- $1 \alpha$ and its target genes such as vascular endothelial growth factor (VEGF) and nitric oxide synthase (NOS). Increased production of VEGF results in disruption of the blood retinal barrier leading to retinal edema. Enhanced expression of NOS results in increased production of nitric oxide which may be toxic to the cells resulting in their death. Excess glutamate release in hypoxic-ischemic conditions causes excitotoxic damage to the RGCs through activation of ionotropic and metabotropic glutamate receptors. Activation of glutamate receptors is thought to initiate damage in the retina by a cascade of biochemical effects such as neuronal NOS activation and increase in intracellular $\mathrm{Ca}^{2+}$ which has been described as a major contributing factor to $\mathrm{RGC}$ loss. Excess production of proinflammatory cytokines also mediates cell damage. Besides the above, free-radicals generated in hypoxic-ischemic conditions result in RGC loss because of an imbalance between antioxidant- and oxidant-generating systems. Although many advances have been made in understanding the mediators and mechanisms of injury, strategies to improve the damage are lacking. Measures to prevent neuronal injury have to be developed.
\end{abstract}

Keywords: retinal hypoxia, retinal ganglion cells, glutamate receptors, neuronal injury, retina

\section{Introduction}

The structural and functional integrity of the retina depends on a regular oxygen supply. Being one of the most metabolically active tissues, retina consumes oxygen more rapidly than other tissues (Cohen and Noell 1965) such as the brain (Anderson and Saltzman 1964; Ames 1992). The presence of a dual circulation (Osborne et al 2004) makes retinal oxygenation unique. The photoreceptors and the greater portion of the outer plexiform layer receive nourishment from the choriocapillaris indirectly whereas the inner retinal layers are supplied by the superficial and deep capillary plexuses formed by branches of the central artery of the retina. Inner layers of the retina are known to show highest sensitivity to hypoxic challenges (Janáky et al 2007), whereas the outer retina is more resistant to a hypoxic stress (Tinjust et al 2002).

Retinal hypoxia occurs in ocular conditions such as central retinal artery occlusion and ischemic central retinal vein thrombosis. Hypoxia is also implicated in the development of glaucoma (Flammer 1994; Tielsch et al 1995; Chung et al 1999; Osborne et al 1999b; Costa et al 2003; Tezel and Wax 2004), diabetes (Linsenmeier et al 1998), and is thought to underlie many of the sight-threatening complications of diabetic eye disease including retinal and optic nerve head neovascularization. Systemic causes of retinal hypoxia include the cardiovascular effects of chronic obstructive airways disease, the ocular ischemic syndrome associated with arterial obstructive conditions such as carotid artery stenosis (Brown and Magargal 1988) and Takayasu's arteritis (Shelhamer et al 1985), hyperviscosity syndromes (Ashton et al 1963) or following trauma (Purtscher's retinopathy; Purtscher 1912; Buckley and James 1997). 
Retinal hypoxia associated with the above conditions is a common cause of visual impairment and blindness (Osborne et al 2004). Retinal ganglion cells (RGCs) have been reported to be particularly sensitive to acute, transient, and mild systemic hypoxic stress (Kergoat et al 2006). Loss of RGCs occurs in many ophthalmic conditions such as glaucoma and diabetes (Sucher et al 1997; Abu-El-Asrar et al 2004), hypoxia being implicated in such a loss (Wax and Tezel 2002; Tezel and Wax 2004; Chen et al 2007). This review details some of the molecular and cellular mechanisms which may be involved in RGC death in ocular conditions associated with hypoxia-ischemia. A better understanding of the mechanisms causing hypoxic damage to RGCs may aid the development of therapies aimed at reducing blindness from retinal hypoxic-ischemic visual loss.

A number of systemic and cellular responses such as glycolysis, angiogenesis, vasodilation, and erythropoiesis enable the organisms to respond to hypoxia (Harris 2002). The neural tissue is capable of inducing protective mechanisms under hypoxic-ischemic conditions (Kitagawa et al 1990) which are induced within minutes and are of putative importance for limiting the damage. However, these protective mechanisms are lost within hours of the hypoxic-ischemic insult (Prass et al 2003) following which cell death and tissue damage occur. Transcriptional activator hypoxia-inducible factor- $1 \alpha$ $(\mathrm{HIF}-1 \alpha)$ is a master regulator of cellular $\mathrm{O}_{2}$ homeostasis (Iyer et al 1998). Hypoxia is known to induce HIF-1 $\alpha$ and its target genes (Bernaudin et al 2002) such as vascular endothelial growth factor (VEGF) and nitric oxide synthase (NOS) in many tissues. Overproduction of these factors has been implicated in neuronal death in hypoxic-ischemic conditions. In addition, enhanced extracellular accumulation of glutamate and inflammatory cytokines damage the neurons. Upregulated expression of HIF-1 $\alpha$, VEGF, and various isoforms of NOS has been reported in the retina following hypoxic injury (Kaur et al 2006) and in the glaucomatous retina (Tezel and Wax 2004).

\section{Retinal ganglion cell death in hypoxia ischemia}

RGC death has been reported to occur in many experimental studies using different methods to induce retinal ischemia (Adachi et al 1996; Goto et al 2002; Lafuente et al 2002; Wang et al 2002; Chidlow and Osborne 2003). Neuronal degeneration resulting from retinal hypoxia-ischemia, caused by oxygen and substrate deprivation, may be mediated by free oxygen radicals (Block and Schwarz 1997; Muller et al 1997; Szabo et al 1997), glutamate excitotoxicity
(Louzada-Junior et al 1992; Osborne et al 2004; Kaur et al 2006), inflammation (Hayashi et al 1996) as well as disruption of the blood retinal barrier (Kuroiwa et al 1985; Kaur et al 2007).

Based on morphological, histochemical, and biochemical criteria, cell death has been classified as apoptotic or necrotic in hypoxic-ischemic conditions (Mehmet et al 1994; Charriaut-Marlangue et al 1996a, 1996b; Chopp and Li 1996; Macaya 1996; Yue et al 1997; MacManus and Linnik 1997; Banasiak and Haddad 1998; Pulera et al 1998; Renolleau et al 1998; Nakajima et al 2000). In necrotic death, swelling of cell body, disruption of plasma membrane, and irregularly scattered condensation of nuclear chromatin occur (Dessi et al 1993; Gwag et al 1997; Sohn et al 1998). In apoptosis, on the other hand, nuclear condensation and contraction occurs early with the membrane and organelles remaining intact until the final stages. Similar necrotic (Buchi 1992; Joo et al 1999) and apoptotic changes in RGCs have been observed in experimental hypoxic-ischemic conditions (Buchi 1992; Joo et al 1996, 1999) as well as in elevated intraocular pressure (Garcia-Valenzuela et al 1995; Quigley et al 1995) and glaucoma (Kerrigan et al 1996) where ischemia is involved in retinal damage directly or indirectly.

Ischemia is known to induce several apoptosis-regulatory genes in cells. Upregulated expression of Bax, a bcl-2 homo$\log$ that effects apoptosis in neurons destined to die, after global ischemia (Krajewski et al 1995; Chen et al 1996) and expression of antiapoptotic gene $b c l-2$ in neurons that survive ischemia (Shimazaki et al 1994; Chen et al 1997) has been reported suggesting that endogenously induced apoptosisregulatory genes may play a role in determining the fate of ischemic neurons. Caspases play a key role in cell death by apoptosis (Jacobson and Evan 1994). Among the caspases, caspase- 3 is activated by many cell death signals and cleaves a variety of important cellular proteins (Jänicke et al 1998; Namura et al 1998). Caspase-3-like protease activation is likely to be relevant in neuronal apoptosis in ischemic injury (Fink et al 1998; Namura et al 1998). Caspase-2 and -3 (Kurokawa et al 1999; Lam et al 1999) and Bax (Kaneda et al 1999) have been reported to be involved in retinal cell loss after ischemic insult.

\section{Hypoxia-ischemia, retinal edema, and vascular endothelial growth factor}

Hypoxia-ischemia underlies various blinding ocular conditions such as diabetic retinopathy and may play a role in the wet form of age-related macular degeneration and in the visual 
loss from retinal detachment (Tso 1982; Yanoff et al 1984; Marmor 1999; Bressler et al 2001; Davis and Blodi 2001; Jackson et al 2003). It is associated with fluid accumulation in the extracellular spaces (vasogenic edema) or intracellulary (cytotoxic edema) in the neural retina (Yanoff et al 1984; Marmor 1999). The extracellular spaces in the inner retina consist of the narrow clefts between the tightly packed cellular elements (Hamann 2002). Fluid leaking out from damaged capillaries in the inner retina accumulates in the extracellular spaces displacing the retinal cellular elements and disrupting the normal anatomy of the neuronal connections (Hamann and La Cour 2005). Factors implicated in pathogenesis of macular edema are retinal ischemia, oxidative stress, and inflammation (Bresnick 1983; Guex-Crosier 1999; van Dam 2002; Miyake and Ibaraki 2002). Increased permeability of blood-retinal barrier (BRB) resulting in fluid accumulation has been reported to contribute to retinal neuronal degeneration by compression (Cunha-Vaz and Travassos 1984; Antcliff and Marshall 1999; Marmor 1999; Reichenbach et al 2007). Excess production of VEGF, nitric oxide (NO) and aquaporin-4 in hypoxic-ischemic insults causes dysfunction of the BRB in the inner retina resulting in serum leakage into the retinal tissues (Marmor 1999; Kaur et al 2007) and retinal edema (Hamann and La Cour 2005). In addition to an increase in vascular permeability, hypoxia has also been correlated with endothelial cell death, leukocyte plugging of vessels, and microaneurysms (Linsenmeier et al 1998).

VEGF, also known as vascular permeability factor (Senger et al 1983), is a key player of angiogenesis in health and disease (Ferrara 2001; Carmeliet 2003). VEGF binds to two tyrosine kinase receptors, VEGFR-1 or fms-like tyrosine kinase Flt-1 and VEGFR-2 or fetal liver kinase receptor Flk-1 to exert its actions (De Vries et al 1992; Quinn et al 1993; Neufeld et al 1999; Shibuya 2001). VEGF is inducible by hypoxia-ischemia in vitro and in vivo and has been suggested as a likely candidate for the development of vasogenic brain edema (Schoch et al 2002). A 3-12-fold increase in VEGF gene expression has been reported in hypoxia (Ikeda et al 1995; Levy et al 1995; Stein et al 1995).

Increased expression of VEGF has been reported in hypoxic brains (Schoch et al 2002; Kaur et al 2006), and astrocytes were identified as the cells expressing VEGF (Kaur et al 2006). Upregulation of endogenous VEGF in astrocytes in hypoxia-ischemia is believed to interact with receptors for VEGF on the vessels and contribute to the disruption of blood-brain barrier (BBB) resulting in vascular leakage (Zhang et al 2000, 2002). Inhibition of VEGF is known to reduce the BBB permeability (Zhang et al 2000).
Similar to the brain, increased production of VEGF and enhanced permeability of BRB was recently reported in the hypoxic retina and inhibition of VEGF production with melatonin reduced BRB permeability (Kaur et al 2006, 2007).

In addition to its role in increasing vascular permeability, VEGF has also been described as an inflammatory mediator which contributes to inflammatory responses observed in cerebral ischemia (Croll et al 2004). The disruption of BBB by VEGF allows contact of normally sequestered central nervous system antigens with blood-borne immune mediators altering the immune privileged status of the brain (Proescholdt et al 1999). VEGF enhances the adhesion of leukocytes to vascular walls and increases intercellular cell adhesion molecule-1(ICAM-1) and vascular cell adhesion molecule-1 (VCAM-1) expression in the brain and retina (Melder et al 1996; Lu et al 1999; Min et al 2005). Overexposure of normal neural tissue to VEGF has been shown to enhance ICAM-1 and major histocompatibility complex class I and II expression (Proescholdt et al 2004). Many changes induced by diabetes such as ICAM-1 up-regulation, leukocyte adhesion and increased vascular permeability in the retina (Murata et al 1996; Amin et al 1997) have been reported to occur in nondiabetic retinas with intravitreous VEGF injections (Tolentino et al 1996; Lu et al 1999) supporting the role of VEGF in inflammation. Suppression of inflammation in retina after VEGF inhibition has been reported (Joussen et al 2002).

Intracellular edema has been reported to occur in ischemia through damage to the cell membrane ionic channels (Marmor 1999). Neuronal and/or glial swelling has been considered as a component of retinal edema. The neuronal cells have been reported to become edematous during ischemia and degenerate eventually in the post-ischemic period (Johnson 1974).

\section{Hypoxia-ischemia and nitric oxide}

$\mathrm{NO}$ is known to play an important role in the pathogenesis of neuronal injury during hypoxia-ischemia. NO is synthesized by the enzyme NOS from L-arginine. NOS exists in three isoforms: neuronal (nNOS) and endothelial (eNOS) which are constitutively expressed and inducible (iNOS). The activities of nNOS and eNOS are stimulated by increases in intracellular calcium whereas iNOS is calcium-independent, and NO generated from this isoform is known to mediate immune functions. Enhanced nNOS, eNOS, and iNOS expression has been reported in the retina in response to hypoxia (Kaur et al 2006). 
NO has been described to have neuroprotective and neurotoxic roles (Iadeacola 1997). NO produced by the eNOS isoform is a protective response as it maintains retinal perfusion in hypoxic-ischemic conditions (Toda et al 2007). Vasodilation occurring after hypoxic-ischemic episodes is mediated by eNOS (Bolanos and Almeida 1999) leading to increased blood flow. Blood vessels in retina showed enhanced expression of eNOS following a hypoxic insult (Kaur et al 2006). However, it has been proposed that besides its beneficial effects of producing vasodilatation and increasing the blood flow, eNOS is also involved in VEGF-induced vascular hyperpermeability (Fukumura et al 2001).

All three types of NOS are produced in the retina in hypoxic-ischemic conditions (Kaur et al 2006) and glial cells have been suggested as the major cell types producing them (Kobayashi et al 2000; Kashiwagi et al 2003). In addition to glial cells, infiltrating leukocytes may also be an important source of iNOS production. The RGCs were also reported to express iNOS and nNOS in the hypoxic retina (Kaur et al 2006). NO production from nNOS and iNOS contributes to cytotoxicity resulting in cell death and axonal damage. Other than generation of free radicals, a number of pathways such as N-methyl-D-aspartate (NMDA)-mediated intracellular $\mathrm{Ca}^{2+}$ influx and CREB-mediated transcription of apoptotic proteins such as Bax, Bad, and Bcl-xl are triggered by NO resulting in neuronal death (Mishra et al 2002, 2006; Zubrow et al 2002a, 2002b). Increased expression of Bax but not Bcl-2 in hypoxic cerebral tissue thus increasing the Bax/Bcl-2 ratio in favor of hypoxia-induced apoptosis has been reported (Mishra et al 2004). In retinal ischemia, RGCs death has been reported to be due to involvement of iNOS as it has been observed that iNOS-positive leukocytes enter the ganglion cell layer and surround the RGCs and cause their degeneration which could be prevented with an inhibitor of iNOS (Neufeld et al 2002).

NO induces the proapoptotic cascade in hypoxic neural tissues by increasing phosphorylation of Bcl-2 (Mishra et al 2004). NO-mediated inactivation of MAPK phosphatases has been described as a potential mechanism of activation of ERK and JNK which leads to phosphorylation of the antiapoptotic protein Bcl-2 (Mishra et al 2004). The antiapoptotic potential of phosphorylated Bcl-2 is lost due to its inability to heterodimerize with the proapoptotic protein Bax, resulting in Bax-mediated activation of caspases and initiation of apoptosis (St. Clair et al 1997, Haldar et al 1996; Hu et al 1998). Other mechanisms by which NO contributes to cytotoxicity may be peroxynitrite-mediated oxidative damage, DNA damage, and energy failure (Beckman et al 1990;
Nguyen et al 1992; Zhang et al 1994; Gross et al 1996). This observation is supported by recent studies which have suggested that peroxynitrite produced by iNOS is a highly reactive oxidant capable of inducing injury to a number of cell types ( $\mathrm{Li}$ et al 2005).

\section{Hypoxia-ischemia and excitotoxicity}

Excitatory amino acids have been reported to play an important role in the development of hypoxic-ischemic retinal injury. Glutamate, the excitatory neurotransmitter in the retina, is released by photoreceptors, bipolar cells and ganglion cells and mediates the transfer of visual signals from the retina to the brain (Massey 1990). However, augmented release of glutamate and its accumulation in extracellular spaces in hypoxic-ischemic conditions leading to activation of glutamate receptors has been implicated in hypoxic/ischemic neuronal death (Benveniste et al 1984; Lu et al 1993). Glutamate neurotoxicity is considered as the underlying problem in retinal neuropathies and neurodegenerative conditions such as glaucoma (Dreyer 1998). Elevation of extracellular glutamate concentration in the retina has been shown to mimic hypoxia induced changes in the electroretinogram (Ikeda et al 1995). Over-activation of glutamate receptors due to excess glutamate accumulation in the retina can contribute to retinal dysfunction (Dreyer 1998; Pang et al 1999).

Glutamate exerts its action through ionotropic (aminomethyl-propionic-acid [AMPA], NMDA, and kainate glutamate receptors) and metabotropic receptors (Brandstätter et al 1998; Gründer et al 2001). The metabotropic glutamate receptors (mGluRs) have been grouped into three main classes, group I (mGluR1 and 5), Group II (mGluR2, 3), and Group III (mGluR 4, 6, 7, 8) according to their amino acid sequence, pharmacological properties and transduction mechanisms (Conn and Pin 1997). RGCs express ionotropic receptors (Hartveit et al 1994; Brandstätter et al 1998) as well as mGluRs (Hartveit et al 1995). Glutamate receptor-mediated damage has been reported to occur in glaucoma, central, and branch retinal arterial and retinal vein occlusions resulting in loss of retinal ganglion cells (Sucher et al 1997).

Neurotoxic effects of glutamate are reported to occur predominantly through activation of ionotropic glutamate receptors (GluR) (Levy et al 1991). NMDA receptors are highly permeable to $\mathrm{Ca}^{2+}$ (MacDermott et al 1986; Hollmann et al 1991; Rörig and Grantyn 1993), their activation resulting in an increase in the intracellular calcium levels (Siliprandi et al 1992; Sucher et al 1990, 1991, 1997). $\mathrm{Ca}^{2+}$ overload has been reported to be a central event in neuronal death during ischemia (Nicotera and Orrenius 1998; Sattler and 
Tymianski 2001). Many cellular functions such as regulation of enzymes require calcium. Abnormal higher concentrations of calcium lead to inappropriate activation of enzymes such as proteases, nucleases, and lipases which are harmful to the cellular constituents, generate free radicals as well as cause mitochondrial failure which results in energy depletion and further free radical production (Dugan et al 1995).

Depolarization of neuronal membranes due to energy failure results in $\mathrm{Ca}^{2+}$ influx through the voltage-dependent $\mathrm{Ca}^{2+}$ channels followed by $\mathrm{Ca}^{2+}$-dependent glutamate release (Katsura et al 1994) which further increases the extracellular accumulation of glutamate. Activation of ionotropic glutamate receptors also results in influx of $\mathrm{Na}^{+}$and $\mathrm{Cl}^{-}$ions, inducing osmotic swelling. Glutamate acting via NMDA receptors activates nNOS (Garthewaite and Garthewaite 1991) and the production of NO (Kiss and Vizi 2001). Expression of ionotropic glutamate receptors (GluR2/3 and NMDA) has been reported to be upregulated in the RGCs in hypoxic-ischemic conditions (Kaur et al 2006).

Glutamate has also been reported to induce and exacerbate cell death by activating group I mGluRs (Allen et al 2001; Hilton et al 2006). Neuronal excitation and excitotoxicity is thought to be potentiated by Group I mGluRs (Buisson and Choi 1995; Pin and Duvoisin 1995; Buisson et al 1996), possibly through their interaction with NMDA receptors (Fitzjohn et al 1996; Bordi and Ugolini 1999). It has been reported that mGluR5 are coexpressed with, and functionally coupled to, NMDA receptors and that activation of mGluR5 enhances NMDA responses in neurons (Jia et al 1998; Awad et al 2000; Salt and Binns 2000) contributing to neuronal death (Bruno et al 2000).

Glutamate is also known to be involved in the production of inflammatory cytokines such as tumor necrosis factor- $\alpha$ (TNF- $\alpha$ ) (De et al 2005). Glutamate-induced activation of AMPA and NMDA receptors has been shown to enhance the production of TNF- $\alpha$ (Noda et al 2000; Matute et al 2001) and interleukin-1 $\beta$ (IL-1 $\beta$ ) (Hagan et al 1996) significantly. Co-operation between glutamate receptors and inflammatory cytokines may be one of the mechanisms involved in cell damage.

Glutamate toxicity also results in glutathione depletion and oxidative stress (Ratan et al 1994). Glutathione is a major cellular antioxidant which protects the cells against oxidative stress (Meister and Anderson 1983; Mizui et al 1992; Bobyn et al 2002). Increase in intracellular reactive oxygen species (ROS) generation in response to glutathione depletion has been reported in several studies (Coyle and Puttfarcken 1993; Tan et al 1998).
Removal of excess glutamate from the extracellular space by glutamate transporters is crucial to terminate glutamate excitotoxicty. Glutamate transporters are responsible for the removal of glutamate from the extracellular fluid in the retina (Danbolt 2001). It has been suggested that excess glutamate accumulation in the extracellular spaces may result from a failure of the glutamate transporters, such as GLAST, in the vicinity of RGCs (Harada et al 2007). Glutamate transporters have been described as necessary to prevent excitotoxic retinal damage and to synthesize glutathione and their deficiency has been reported to result in RGC degeneration (Harada et al 2007).

\section{Hypoxia-ischemia and reactive oxygen species}

Hypoxia-ischemia results in perturbation of the cellular prooxidant-antioxidant balance by accumulation of ROS, known as oxidative stress, which has been implicated as an important mechanism of cytotoxicity. In vitro studies have shown that ROS generation in hypoxic-ischemic conditions in neurons occurs from three sources: mitochondria generating an initial burst of ROS followed by a second phase of ROS generation due to xanthine oxidase activation and a third phase of $\mathrm{Ca}^{2+}-$ dependent ROS generation (Abramov et al 2007).

ROS are known to cause lipid peroxidation, protein oxidation, and DNA oxidation, which contributes to neurodegeneration (Hall and Braugher 1989; Chan 1994, 1996). ROS can also stimulate ischemic cells to secrete inflammatory cytokines and chemokines which induce cell damage and disruption of BBB (Wang et al 2007). ROS have been reported to be cytotoxic to RGCs (Tezel and Yang 2004) causing necrotic cell death by direct oxidative damage to cellular constituents and apoptotic death by participating in the signal transduction pathway for apoptosis (Kortuem et al 2000; Levkovitch-Verbin et al 2000; Lieven et al 2003, 2006; Nguyen et al 2003).

NO, a free radical is produced by the endothelial cells and serves as a vasodilator (Garthwaite et al 1988; Lamas et al 1992; Southam and Garthwaite 1993; Iadecola et al 1994). However, NO, as mentioned above, can also be neurotoxic causing neuronal death in hypoxic and excitotoxic insults (Dawson et al 1991; Moncada et al 1991; Boje and Arora 1992; Lees 1993). It has been shown that NO can react with the superoxide anion $\left(\mathrm{O}_{2}^{-}\right)$to form peroxynitrite $\left(\mathrm{OONO}^{-}\right)$ (Beckman et al 1990) which is neurotoxic (Lipton et al 1993). NO alone, even at high levels, has been reported as nontoxic to cortical neurons, but becomes neurotoxic after its reaction with $\mathrm{O}_{2}^{-}$to form $\mathrm{ONOO}^{-}$(Lipton et al 1993). In vitro 
studies have shown that formation of $\mathrm{OONO}^{-}$increases the VEGF-induced permeability of retinal microvascular endothelial cells (Marumo et al 1999) and tissue damage through DNA damage, lipid peroxidation, and reduced cellular antioxidant defenses (Salgo et al 1995; Salvemini et al 1998).

\section{Hypoxia-ischemia and inflammation}

Hypoxia is known to regulate expression of many genes modulating inflammation (Hedtjärn et al 2004). An acute inflammatory reaction, characterized by increased expression of proinflammatory mediators (Szaflarski et al 1995; Bona et al 1999), a rapid microglial/monocytic response (Ivako et al 1996) and gliosis (Burtrum et al 1994), have been reported to be elicited in the brain by hypoxia-ischemia (Cowell et al 2002). Many cell types including injured neurons have been reported as a major source of chemokines such as monocyte chemoattractant protein (MCP-1) (Ivako et al 1997) whereas expression of macrophage inflammatory protein- $\alpha$ has been reported in monocytes and activated microglial cells (Cowell et al 2002) in hypoxic-ischemic brain injury. Chemokine receptors CCR2 and CCR5 have also been reported to be upregulated (Hedtjärn et al 2004). Chemokine expression may play a role in leukocyte recruitment and infiltration in the inner retina, leading to RGC damage (Jo et al 2003). Leukocytes are known to play a central role in post-ischemic tissue damage (del-Zoppo et al 1991; Heinel et al 1994; Zhang et al 1994) by producing free radicals (Werns et al 1985) and inflammatory cytokines (Ghezzi et al 1991).

Hypoxia-ischemia is known to attract macrophages to hypoxic areas through expression of MCP-1.
The hypoxia-activated macrophages and microglia, the immune effector cells in the retina, release TNF- $\alpha$ which has been reported as a triggering factor to activate production of interleukin-8 (IL-8), VEGF, or MCP-1 in retinal vascular cells and/or glial cells adjacent to microvessels (Yoshida et al 2004). Expression of TNF- $\alpha$ and cyclooxygenase-2 (COX-2) was reported recently in the ischemic retina (Zheng et al 2007). Several inflammatory molecules including ICAM-1, TNF- $\alpha$, IL-1 $\beta$, iNOS, and COX-2 released by activated inflammatory cells and glial elements play a major role in degeneration of retinal capillaries (Joussen et al 2004; Zheng et al 2007) and subsequently the RGCs.

Expression of adhesion molecules, ICAM-1 and VCAM-1, on the endothelial cells facilitating leukocyte adhesion and infiltration into the areas of damage has been reported to be induced by TNF- $\alpha$ (Wong and Dorovini, 1992; Hess et al 1994; McHale et al 1999). In vitro studies have shown that IL- $1 \beta$ and TNF- $\alpha$ induce ICAM- 1 expression in endothelial cells (Feuerstein et al 1998). ICAM-1 is important for establishing adhesion of leukocytes before their movement across the endothelium into the tissue (Wang et al 1994).

IL- $1 \beta$ and TNF- $\alpha$ may also be involved in transcriptional activation of the iNOS gene (Lopez-Figueroa et al 2000; Kadhim et al 2006). Endothelial cells of brain microvessels are known to express iNOS and produce large amounts of NO under inflammatory conditions as IL-1 $\beta$ has an important role in iNOS expression and NO generation (Betz et al 1996; Bonmann et al 1997). Induction of IL-1 $\beta$ gene expression in the vascular wall, accompanied by perivascular induction of

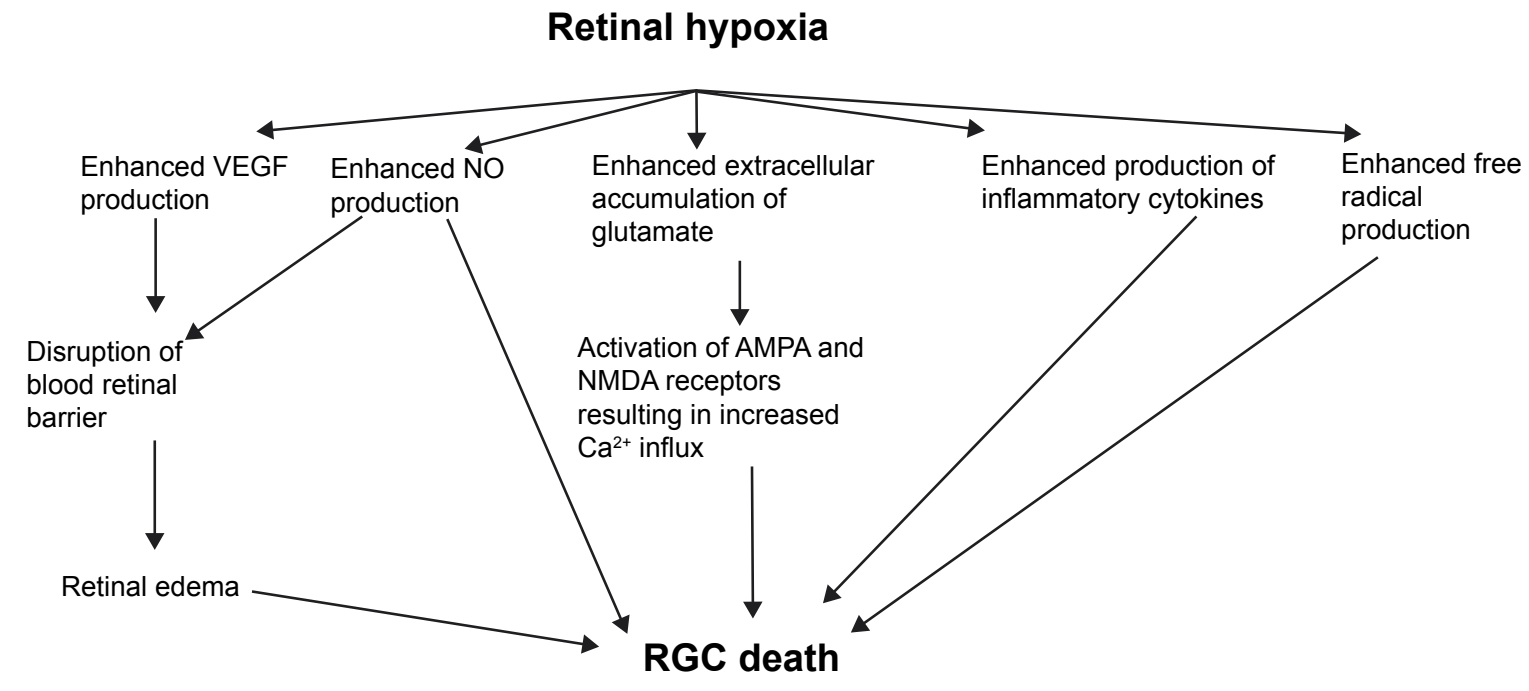

Figure I Potential mediators of RGC death in retinal hypoxia-ischemia. 
iNOS mRNA was observed in the rat brain during systemic inflammation (Wong et al 1996). Increased release of IL-1 $\beta$ and TNF- $\alpha$ in the retina in hypoxic-ischemic conditions may have a similar action.

\section{Conclusion}

Retinal hypoxia results in increased release VEGF, NO, glutamate, inflammatory cytokines and ROS (Figure 1). These processes result in RGC loss through various mechanisms such as disruption of BRB, excitotoxicity and increased accumulation of intracellular $\mathrm{Ca}^{2+}$. Understanding of the processes outlined in this review may provide new strategies to minimize RGC loss and possibly counteract or prevent it.

\section{Acknowledgments}

This study was supported by a research grant (R181000-098-112) from the National University of Singapore, Singapore. The help provided by Dr. V. Sivakumar in the preparation of this manuscript is gratefully acknowledged. The authors report no conflicts of interest in this work.

\section{References}

Abramov AY, Scorziello A, Duchen MR. 2007. Three distinct mechanisms generate oxygen free radicals in neurons and contribute to cell death during anoxia and reoxygenation. J Neurosci, 27:1129-38.

Abu-El-Asrar AM, Dralands L, Missotten L, et al. 2004. Expression of apoptosis markers in the retinas of human subjects with diabetes. Invest Ophthalmol Vis Sci, 45:2760-6.

Adachi M, Takahashi K, Nishikawa M, et al. 1996. High intraocular pressure-induced ischemia and reperfusion injury in the optic nerve and retina in rats. Graefes Arch Clin Exp Ophthalmol, 234:445-51.

Allen JW, Vicini S, Faden AI. 2001. Exacerbation of neuronal cell death by activation of group I metabotropic glutamate receptors: role of NMDA receptors and arachidonic acid release. Exp Neurol, 169:449-60.

Ames A. 1992. Energy requirements of CNS cells as related to their function and to their vulnerability to ischemia: a commentary based on studies on retina. Can J Physiol Pharmacol, 70(Suppl):S158-64.

Amin RH, Frank RN, Kennedy A, et al. 1997. Vascular endothelial growth factor is present in glial cells of the retina and optic nerve of human subjects with nonproliferative diabetic retinopathy. Invest Ophthalmol Vis Sci, 38:36-47.

Anderson B, Saltzman HA. 1964. Retinal oxygen utilization measured by hyperbaric blackout. Arch Ophthalmol, 72:792-5.

Antcliff RJ, Marshall J. 1999. The pathogenesis of edema in diabetic maculopathy. Semin Ophthalmol, 14:223-32.

Ashton N, Kok DA, Foulds WS. 1963. Ocular pathology in macroglobulinaemia. J Pathol Bacteriol, 86:453-61.

Awad H, Hubert GW, Smith Y, et al. 2000. Activation of metabotropic glutamate receptor 5 has direct excitatory effects and potentiates NMDA receptor currents in neurons of the subthalamic nucleus. $J$ Neurosci, 20:7871-9.

Banasiak KJ, Haddad GG. 1998. Hypoxia-induced apoptosis: effect of hypoxic severity and role of p53 in neuronal cell death. Brain Res, 797:295-304.

Beckman JS, Beckman TW, Chen J, et al. 1990. Apparent hydroxyl radical production by peroxynitrite: implications for endothelial injury from nitric oxide and superoxide. Proc Natl Acad Sci US A, 87:1620-24.
Benveniste H, Drejer J, Schousboe A, et al. 1984. Elevation of the extracellular concentrations of glutamate and aspartate in rat hippocampus during transient cerebral ischemia monitored by intracerebral microdialysis. J Neurochem, 43:1369-74.

Bernaudin M, Nedelec AS, Divoux D, et al. 2002. Normobaric hypoxia induces tolerance to focal permanent cerebral ischemia in association with an increased expression of hypoxia-inducible factor-1 and its target genes, erythropoietin and VEGF, in the adult mouse brain. $J$ Cereb Blood Flow Metab, 22:393-403.

Betz AL, Schielke GP, Yang GY. 1996. Interleukin-1 in cerebral ischemia. Keio J Med, 45:230-7.

Block F, Schwarz M. 1997. Effects of antioxidants on ischemic retinal dysfunction. Exp Eye Res, 64:559-64.

Bobyn PJ, Franklin JL, Wall CM, et al. 2002. The effects of dietary sulfur amino acid deficiency on rat brain glutathione concentration and neural damage in global hemispheric hypoxia-ischemia. Nutr Neurosci, 5:407-16.

Boje KM, Arora PK. 1992. Microglial-produced nitric oxide and reactive nitrogen oxides mediate neuronal cell death. Brain Res, 587:250-6.

Bolanos JP, Almeida A. 1999. Roles of nitric oxide in brain hypoxiaischemia. Biochim Biophys Acta, 1411:415-36.

Bona E, Andersson AL, Blomgren K, et al. 1999. Chemokine and inflammatory cell response to hypoxia-ischemia in immature rats. Pediatr Res, 45:500-9.

Bonmann E, Suschek C, Spranger M, et al. 1997. The dominant role of exogenous or endogenous interleukin-1 beta on expression and activity of inducible nitric oxide synthase in rat microvascular brain endothelial cells. Neurosci Lett, 230:109-12.

Bordi F, Ugolini A. 1999. Group I metabotropic glutamate receptors: implications for brain diseases. Prog Neurobiol, 59:55-79.

Brandstätter JH, Koulen P, Wässle H. 1998. Diversity of glutamate receptors in the mammalian retina, Vision Res, 38:1385-97.

Bresnick GH. 1983. Diabetic maculopathy. A critical review highlighting diffuse macular edema. Ophthalmology, 90:1301-17.

Bressler NM, Bressler SB, Fine SL. 2001. Neovascular (exudative) agerelated macular degeneration. In: Schachat AP (ed). Retina. St. Louis, MO: Mosby, pp. 1100-35.

Brown GC, Magargal LE. 1988. The ocular ischemic syndrome. Clinical, fluorescein angiographic and carotid angiographic features. Int Ophthalmol, 11:239-51.

Bruno V, Battaglia G, Ksiazek I, et al. 2000. Selective activation of mGlu4 metabotropic glutamate receptors is protective against excitotoxic neuronal death. J Neurosci, 20:6413-20.

Buchi ER. 1992. Cell death in the rat retina after a pressure-induced ischemia-reperfusion insult: an electron microscopic study, I: Ganglion cell layer and inner nuclear layer. Exp Eye Res, 55:605-13.

Buckley SA, James B. 1996. Purtscher's retinopathy. Postgrad Med J, 72:409-12.

Buisson A, Choi DW. 1995. The inhibitory mGluR agonist, S-4-carboxy3-hydroxy-phenylglycine selectively attenuates NMDA neurotoxicity and oxygen-glucose deprivation-induced neuronal death. Neuropharmacology, 34:1081-7.

Buisson A, Yu SP, Choi DW. 1996. DCG-IV selectively attenuates rapidly triggered NMDA-induced neurotoxicity in cortical neurons. Eur J Neurosci, 8:138-43.

Burtrum D, Silverstein FS. 1994. Hypoxic-ischemic brain injury stimulates glial fibrillary acidic protein $\mathrm{mRNA}$ and protein expression in neonatal rats. Exp Neurol, 126:112-8.

Carmeliet P. 2003. Angiogenesis in health and disease. Nat Med, 9:653-60.

Chan PH. 1994. Oxygen radicals in focal cerebral ischemia. J Brain Pathol, 4:59-65.

Chan PH. 1996. Role of oxidants in ischemic brain damage. Stroke, 27:1124-9.

Charriaut-Marlangue C, Margaill I, Borrega F, et al. 1996b. NG-nitro-L-arginine methyl ester reduces necrotic but not apoptotic cell death induced by reversible focal ischemia in rat. Eur J Pharmacol, 310:137-40. 
Charriaut-Marlangue C, Pollard H, Ben-Ari Y. 1996a. Is ischemic cell death of the apoptotic type? Adv Neurol, 71:425-30.

Chen HL, Pistollato F, Hoeppner DJ, et al. 2007.Oxygen tension regulates survival and fate of mouse central nervous system precursors at multiple levels. Stem Cells, 25:2291-301.

Chen J, Graham SH, Nakayama M, et al. 1997. Apoptosis repressor genes $\mathrm{Bcl}-2$ and Bcl-x-long are expressed in the rat brain following global ischemia. J Cereb Blood Flow Metab, 17:2-10.

Chen J, Zhu RL, Nakayama M, et al. Expression of the apoptosis-effector gene, Bax, is up-regulated in vulnerable hippocampal CA1 neurons following global ischemia. J Neurochem, 67:64-71.

Chidlow G, Osborne NN. 2003. Rat retinal ganglion cell loss caused by kainate, NMDA and ischemia correlates with a reduction in mRNA and protein of Thy-1 and neurofilament light. Brain Res, 963:298-306.

Chopp M, Li Y. 1996. Apoptosis in focal cerebral ischemia. Acta Neurochir Suppl, 66:21-6.

Chung HS, Harris A, Evans DW, et al. 1999. Vascular aspects in the pathophysiology of glaucomatous optic neuropathy. Surv Ophthalmol, 43(Suppl 1):S43-50.

Cohen LH, Noell WK. 1965. Relationships between visual function and metabolism. In: Graymore CN, (ed). Biochemistry of the Retina. Orlando, Fla: Academic Press Inc, pp. 36-50.

Conn JP, Pin JP. 1997. Pharmacology and functions of metabotropic glutamate receptors. Ann Rev Pharmacol Toxicol, 37:205-37.

Costa VP, Harris A, Stefánsson E, et al. 2003. The effects of antiglaucoma and systemic medications on ocular blood flow. Prog Retin Eye Res, 22:769-805.

Cowell RM, Xu H, Galasso JM, et al. 2002. Hypoxic-ischemic injury induces macrophage inflammatory protein-1alpha expression in immature rat brain. Stroke, 33:795-801.

Coyle JT, Puttfarcken P. 1993. Oxidative stress, glutamate, and neurodegenerative disorders. Science, 262:689-95.

Croll SD, Ransohoff RM, Cai N, et al. 2004. VEGF-mediated inflammation precedes angiogenesis in adult brain. Exp Neurol, 187:388-402.

Cunha-Vaz JG, Travassos A. 1984. Breakdown of the blood-retinal barriers and cystoid macular edema. Surv Ophthalmol, 28:S485-92.

Danbolt NC. 2001. Glutamate uptake. Prog Neurobiol, 65:1-105

Davis MD, Blodi BA. 2001. Proliferative diabetic retinopathy. In: Schachat AP (ed). Retina. St. Louis, MO: Mosby, pp. 1309-49.

Dawson VL, Dawson TM, London ED, et al. 1991. Nitric oxide mediates glutamate neurotoxicity in primary cortical cultures. Proc Natl Acad Sci U S A, 88:6368-71.

De A, Krueger JM, Simasko SM. 2005. Glutamate induces the expression and release of tumor necrosis factor-alpha in cultured hypothalamic cells. Brain Res, 1053:54-61.

De Vries C, Escobedo JA, Ueno H, et al. 1992. The fms-like tyrosine kinase, a receptor for vascular endothelial growth factor. Science, 255:989-91.

del-Zoppo GJ, Schmid-Schonbein GW, Mori E, et al. 1991. Polymorphonuclear leukocytes occlude capillaries following middle cerebral artery occlusion and reperfusion in baboons. Stroke, 22:1276-83.

Dessi F, Charriaut-Marlangue C, Khrestchatisky M, et al. 1993.Glutamateinduced neuronal death is not a programmed cell death in cerebellar cultures. J Neurochem, 60:1953-5.

Drance SM, Douglas GR, Wijsman K, et al. 1988. Response of blood flow to warm and cold in normal and low-tension glaucoma patients. Am J Ophthalmol, 105:35-9.

Dreyer EB. 1998. A proposed role for excitotoxicity in glaucoma. J Glaucoma, 7:62-7.

Dugan LL, Sensi SL, Canzoniero LM, et al. 1995. Mitochondrial production of reactive oxygen species in cortical neurons following exposure to N-methyl-d-aspartate. J Neurosci, 15:6377-88.

Ferrara N. 2001. Role of vascular endothelial growth factor in regulation of physiological angiogenesis. Am J Physiol Cell Physiol, 280: C1358-66.

Feuerstein G, Wang X, Barone FC. 1998. Cytokines in brain ischemia - the role of TNF alpha. Cell Mol Neurobiol, 18:695-701.
Fink K, Zhu J, Namura S, et al. 1998. Prolonged therapeutic window for ischemic brain damage caused by delayed caspase activation. $J$ Cereb Blood Flow Metab, 18:1071-6.

Fitzjohn SM, Irving AJ, Palmer MJ, et al. 1996. Activation of group I mGluRs potentiates NMDA responses in rat hippocampal slices. Neurosci Lett, 203:211-3.

Flammer J. 1994. The vascular concept of glaucoma. Surv Ophthalmol, 38(Suppl):S3-6.

Fukumura D, Gohongi T, Kadambi A, et al. 2001. Predominant role of endothelial nitric oxide synthase in vascular endothelial growth factorinduced angiogenesis and vascular permeability. Proc Natl Acad Sci US A, 98:2604-9.

Garcia-Valenzuela E, Shareef S. Walsh J, et al. 1995. Programmed cell death of retinal ganglion cells during experimental glaucoma. Exp Eye Res, 61:33-44.

Garthwaite G, Garthwaite J. 1991. AMPA neurotoxicity in rat cerebellar and hippocampal slices: histological evidence for three mechanisms. Eur J Neurosci, 3:715-28.

Garthwaite J, Charkes SL, Chess-Williams R. 1988. Endothelium-derived relaxing factor release on activation of NMDA receptors suggests role as intercellular messenger in the brain. Nature, 336:385-8.

Garthwaite J. 1991. Glutamate, nitric oxide and cell-cell signalling in the nervous system. Trends Neurosci, 14:60-7.

Ghezzi P, Dinarello CA, Bianchi M, et al. 1991. Hypoxia increases production of interleukin-1 and tumor necrosis factor by human mononuclear cells. Cytokine, 3:189-94.

Goto W, Ota T, Morikawa N, et al. 2002. Protective effects of timolol against the neuronal damage induced by glutamate and ischemia in the rat retina. Brain Res, 958:10-9.

Gross WL, Bak MI, Ingwall JS, et al. 1996. Nitric oxide inhibits creatine kinase and regulates rat heart contractile reserves. Proc Natl Acad Sci U S A, 93:5604-9.

Gründer T, Kohler K, Guenthe E. 2001. Alterations in NMDA receptor expression during retinal degeneration in the RCS rat, Vis Neurosci, 18:781-7.

Guex-Crosier Y. 1999. The pathogenesis and clinical presentation of macular edema in inflammatory diseases. Doc Ophthalmol, 97:297-309.

Gwag BJ, KohJY, DemaroJ, et al. 1997. Slowly triggered excitotoxicity occurs by necrosis in cortical cultures. Neuroscience, 77:393-401.

Hagan P, Poole S, Bristow AF, et al. 1996. Intracerebral NMDA injection stimulates production of interleukin- $1 \beta$ in perinatal rat brain. $J$ Neurochem, 67:2215-8.

Haldar S, Chintapalli J, Croce CM. 1996. Taxol induces bcl-2 phosphorylation and death of prostate cancer cells. Cancer Res, 56:253-5.

Hall ED, Braughler JM. 1989. Central nervous system trauma and stroke. II. Physiological and pharmacological evidence for involvement of oxygen radicals and lipid peroxidation. Free Radic Biol Med, 6:303-13.

Hamann KF. 2002. [Driving ability with vestibulär lesions]. HNO, 50:1086-8

Hamann S, la Cour M. 2005. Water homeostasis in the ischaemic retina: is aquaporin-4 involved? Acta Ophthalmol Scand, 83:523-5.

Harada T, Harada C, Nakamura K, et al. 2007. The potential role of glutamate transporters in the pathogenesis of normal tension glaucoma. $J$ Clin Invest, 117:1763-70.

Harris AL. 2002. Hypoxia - a key regulatory factor in tumour growth. Nat Rev Cancer, 2:38-47.

Hartveit E, Brandstätter JH, Enz R, et al. 1995. Expression of the mRNA of seven metabotropic glutamate receptors (mGluR1-7) in the rat retina. An in situ hybridization study on tissue sections and isolated cells. Eur J Neurosci, 7:1472-83.

Hartveit E, Brandstätter JH, Sassoè-Pognetto M, et al. 1994. Localization and developmental expression of the NMDA receptor subunit NR2A in the mammalian retina. J Comp Neurol, 348:570-82.

Hedtjärn M, Mallard C, Hagberg H. 2004. Inflammatory gene profiling in the developing mouse brain after hypoxia-ischemia. $J$ Cereb Blood Flow Metab, 24:33-51. 
Heinel LA, Rubin S, Rosenwasser RH, et al. 1994. Leukocyte involvement in cerebral infarct generation after ischemia and reperfusion. Brain Res Bull, 34:137-41.

Hess DC, Bhutwala T, Sheppard JC, et al. 1994. ICAM-1 expression on human brain microvascular endothelial cells. Neurosci Lett, 168:201-4.

Hilton GD, Nunez JL, Bambrick L, et al. 2006. Glutamate-mediated excitotoxicity in neonatal hippocampal neurons is mediated by mGluRinduced release of $\mathrm{Ca}++$ from intracellular stores and is prevented by estradiol. Eur J Neurosci, 24:3008-16.

Hollmann M, Hartley M, Heinemann S. 1991. $\mathrm{Ca}^{2+}$ permeability of KA-AMPA - gated glutamate receptor channels depends on subunit composition. Science, 252:851-3.

Hu Y, Benedict MA, Wu D, et al. 1998. Bcl-XL interacts with Apaf-1 and inhibits Apaf-1-dependent caspase-9 activation. Proc Natl Acad Sci US A, 9:4386-91.

Iadecola C, Pelligrino DA, Moskowitz MA, et al. 1994. State of the art review: nitric oxide synthase inhibition and cerebrovascular regulation. $J$ Cereb Blood Flow Meta, 14:175-92.

Iadecola C. 1997. Bright and dark sides of nitric oxide in ischemic brain injury. Trends Neurosci, 20:132-9.

Ikeda E, Achen MG, Breier G, et al. 1995. Hypoxia-induced transcriptional activation and increased mRNA stability of vascular endothelial growth factor in C6 glioma cells. J Biol Chem, 270:19761-6.

Ivako J, Malinak C, Malinak C. 1997. Hypoxic ischemic injury induces monocyte chemoattractant protein 1 expression in neonatal rat brain J Cereb Blood Flow Metab, 17:759-70.

Ivako J, Silverstein FS, Silverstein FS. 1996. Hypoxic ischemic brain injury induces an acute microglial reaction inperinatal rats Pediat Res, 39:39-47.

Iyer NV, Kotch LE, Agani F, et al. 1998. Cellular and developmental control of $\mathrm{O} 2$ homeostasis by hypoxia-inducible factor 1 alpha. Genes Dev, 12:149-62.

Jackson TL, Hillenkamp J, Williamson TH, et al. 2003. An experimental model of rhegmatogenous retinal detachment: surgical results and glial cell response. Invest Ophthalmol Vis Sci, 44: 4026-34.

Jacobson MD, Evan GI. 1994. Apoptosis. Breaking the ICE. Curr Biol, 4:337-40.

Janáky M, Grósz A, Tóth E, et al. 2007. Hypobaric hypoxia reduces the amplitude of oscillatory potentials in the human ERG. Doc Ophthalmol, 114:45-51.

Jänicke RU, Sprengart ML, Wati MR, et al. 1998. Caspase-3 is required for DNA fragmentation and morphological changes associated with apoptosis. $J$ Biol Chem, 273:9357-60.

Jia Z, Lu Y, Henderson J, et al. 1998. Selective abolition of the NMDA component of long-term potentiation in mice lacking mGluR5. Learn Mem, 5:331-43.

Jo N, Wu GS, Rao NA. 2003. Upregulation of chemokine expression in the retinal vasculature in ischemia-reperfusion injury. Invest Ophthalmol Vis Sci, 44:4054-60.

Johnson NF. 1974. Effects of acute ischemia on the structure of the rabbit retina. Trans Ophthalmol Soc Uk, 94:394-405.

Joo CK, Choi JS, Ko HW, et al. 1999. Necrosis and apoptosis after retinal ischemia: involvement of NMDA-mediated excitotoxicity and p53. Invest Ophthalmol Vis Sci, 40:713-20.

Joo CK, Park KY, Park MS, et al. 1996. Occurrence of neuronal necrosis and apoptosis following the retinal ischemia: induction of p53 and bcl-2 mRNA. Soc Neurosci Abstr, 26:464-15.

Joussen AM, Poulaki V, Le ML, et al. 2004 . A central role for inflammation in the pathogenesis of diabetic retinopathy. FASEB J, 18:1450-2.

Joussen AM, Poulaki V, Qin W, et al. 2002. Retinal vascular endothelial growth factor induces intercellular adhesion molecule-1 and endothelial nitric oxide synthase expression and initiates early diabetic retinal leukocyte adhesion in vivo Am J Pathol, 160:501-9.

Kadhim H, Khalifa M, Deltenre P, et al. 2006 . Molecular mechanisms of cell death in periventricular leukomalacia. Neurology, 67:293-9.
Kaneda K, Kashii S, Kurosawa T, et al. 1999. Apoptotic DNA fragmentation and upregulation of Bax induced by transient ischemia of the rat retina. Brain Res, 815:11-20.

Kashiwagi K, Iizuka Y, Mochizuki S, et al. 2003. Differences in nitric oxide production: a comparison of retinal ganglion cells and retinal glial cells cultured under hypoxic conditions. Brain Res Mol Brain Res, 112:126-34.

Katsura K, Kristian T, Siesjo BK. 1994. Energy metabolism, ion homeostasis, and cell damage in the brain. Biochem Soc Trans, 22:991-6.

Kaur C, Sivakumar V, Foulds WS. 2006. Early response of neurons and glial cells to hypoxia in the retina. Invest Ophthalmol Vis Sci, 47:1126-41.

Kaur C, Sivakumar V, Yong Z, et al. 2007. Blood-retinal barrier disruption and ultrastructural changes in the hypoxic retina in adult rats: the beneficial effect of melatonin administration. J Pathol, 212:429-39.

Kergoat H, Hérard ME, Lemay M. 2006. RGC sensitivity to mild systemic hypoxia. Invest Ophthalmol Vis Sci, 47:5423-7.

Kerrigan LA, Zack DJ, Quigley HA, et al. 1997. TUNEL-positive ganglion cells in human primary open-angle glaucoma. Arch Ophthalmol, 1151031-5.

Kiss JP, Vizi ES. 2001. Nitric oxide: a novel link between synaptic and nonsynaptic transmission. Trends Neurosci, 24:211-5.

Kitagawa K, Matsumoto M, Tagaya M, et al. 1990. Ischemic tolerance' phenomenon found in the brain. Brain Res, 528:21-4.

Kobayashi M, Kuroiwa T, Shimokawa R, et al. 2000. Nitric oxide synthase expression in ischemic rat retinas. Jpn J Ophthalmol, 44:235-44.

Kortuem K, Geiger LK, Levin LA. 2000. Differential susceptibility of retinal ganglion cells to reactive oxygen species. Invest Ophthalmol Vis Sci, 41:3176-82.

Krajewski S, Mai JK, Krajewska M, et al. 1995. Upregulation of bax protein levels in neurons following cerebral ischemia. $J$ Neurosci, 15:6364-76

Kuroiwa T, Ting P, Martinez H, et al. 1985. The biphasic opening of the blood-brain barrier to proteins following temporary middle cerebral artery occlusion. Acta Neuropathol (Berl), 68:122-9.

Kurokawa H, Nishio K, Fukumoto H, et al. 1999. Alteration of caspase-3 (CPP32/Yama/apopain) in wild-type MCF-7, breast cancer cells. Oncol Rep, 6:33-7.

Lafuente MP, Villegas-Perez MP, Sells-Navarro I, et al. 2002. Retinal ganglion cell death after acute retinal ischemia is an ongoing process whose severity and duration depends on the duration of the insult. Neuroscience, 109:157-68.

Lam TT, Abler AS, Tso MO. 1999. Apoptosis and caspases after ischemia-reperfusion injury in rat retina. Invest Ophthalmol Vis Sci, 40:967-75.

Lamas S, Marsden PA, Li GK. 1992. Endothelial nitric oxide synthase: molecular cloning and characterization of a distinct constitutive enzyme isoform. Proc Natl Acad Sci U S A, 89:6348-52.

Lees GJ. 1993. The possible contribution of microglia and macrophages to delayed neuronal death after ischemia. J Neurol Sci, 114:119-22.

Levkovitch-Verbin H, Harris-Cerruti C, Groner Y, et al. 2000. RGC death in mice after optic nerve crush injury: oxidative stress and neuroprotection. Invest Ophthalmol Vis Sci, 41:4169-74.

Levy AP, Levy NS, Wegner S, et al. 1995. Transcriptional regulation of the rat vascular endothelial growth factor gene by hypoxia. $J$ Biol Chem, 270:13333-40.

Li TQ, Mathews VP, Wang Y, et al. 2005. Adolescents with disruptive behavior disorder investigated using an optimized MR diffusion tensor imaging protocol. Ann N Y Acad Sci, 1064:184-92.

Lieven CJ, Schlieve CR, Hoegger MJ, et al. 2006. Retinal ganglion cell axotomy induces an increase in intracellular superoxide anion. Invest Ophthalmol Vis Sci, 47:1477-85.

Lieven CJ, Vrabec JP, Levin LA. 2003. The effects of oxidative stress on mitochondrial transmembrane potential in retinal ganglion cells Antioxid Redox Signal, 5:641-6.

Linsenmeier RA, Braun RD, McRipley MA, et al. 1998. Retinal hypoxia in long-term diabetic cats. Invest Ophthalmol Vis Sci, 39:1647-57. 
Lipton SA, Choi YB, Pan ZH, et al. 1993. A redox-based mechanism for the neuroprotective and neurodestructive effects of nitric oxide and related nitroso-compounds. Nature, 364:626-32.

López-Figueroa MO, Day HE, Lee S, et al. 2000. Temporal and anatomical distribution of nitric oxide synthase mRNA expression and nitric oxide production during central nervous system inflammation. Brain Res, 852:239-46.

Louzada-Junior P, Dias JJ, Santos WF, et al. 1992. Glutamate release in experimental ischaemia of the retina: an approach using microdialysis. J Neurochem, 59:358-63.

Lu M, Perez V, Ma N, et al. 1999. VEGF increases retinal vascular ICAM-1 expression in vivo. Invest Ophthalmol Vis Sci, 40:1808-12.

$\mathrm{Lu} \mathrm{Y,} \mathrm{Lu} \mathrm{BF,} \mathrm{Zhao} \mathrm{FQ,} \mathrm{et} \mathrm{al.} \mathrm{1993.} \mathrm{Accumulation} \mathrm{of} \mathrm{glutamate} \mathrm{is} \mathrm{regulated}$ by calcium and protein kinase $\mathrm{C}$ in rat hippocampal slices exposed to ischemic states. Hippocampus. 3:221-7.

Macaya A. 1996. [Apoptosis in the nervous system]. Rev Neurol, 24:1356-60.

MacDermott AB, Mayer ML, Westbrook GL, et al. 1986. NMDA-receptor activation increases cytoplasmic calcium concentration in cultured spinal cord neurones. Nature, 321:519-22.

MacManus JP, Linnik MD. 1997. Gene expression induced by cerebral ischemia: an apoptotic perspective. J Cereb Blood Flow Metab, 17:815-32.

MacManus JP, Linnik MD. 1997. Gene expression induced by cerebral ischemia: an apoptotic perspective. J Cereb Blood Flow Metab, 17:815-32.

Marmor MF. 1999. Mechanisms of fluid accumulation in retinal edema. Doc Ophthalmol, 97:239-49.

Marumo T, Noll T, Schini-Kerth VB, et al. 1999. Significance of nitric oxide and peroxynitrite in permeability changes of the retinal microvascular endothelial cell monolayer induced by vascular endothelial growth factor. J Vasc Res, 36:510-15.

Massey SC. 1990. Cell types using glutamate as a neurotransmitter in the vertebrate retina. Progr Retinal Res, 9:399-425.

Matute C, Alberdi E, Domercq M, et al. 2001. The link between excitotoxic oligodendroglial death and demyelinating diseases. Trends Neurosci, 24:224-30.

McHale JF, Harari OA, Marshall D, et al. 1999. TNF-alpha and IL-1 sequentially induce endothelial ICAM-1 and VCAM-1 expression in MRL/lpr lupus-prone mice. J Immunol, 163:3993-4000.

Mehmet H, Yue X, Squier MV, et al. 1994. Increased apoptosis in the cingulate sulcus of newborn piglets following transient hypoxia-ischaemia is related to the degree of high energy phosphate depletion during the insult. Neurosci Lett, 181:121-5.

Meister A, Anderson ME. 1983. Glutathione. Annu Rev Biochem, 52:711-60.

Melder, RJ, Koenig, GC, Witwer, BP, et al. 1996. During angiogenesis, vascular endothelial growth factor and basic fibroblast growth factor regulate natural killer cell adhesion to tumor endothelium. Nat Med, 2:992-7.

Min JK, Kim YM, Kim SW, et al. 2005. TNF-related activation-induced cytokine enhances leukocyte adhesiveness: Induction of ICAM-1 and VCAM-1 via TNF receptor-associated factor and protein kinase C-dependent NFB activation in endothelial cells. The Journal of Immunol, 175:531-40.

Mishra OP, Ashraf QM. Delivoria-Papadopoulos M. 2002. Phosphorylation of cAMP response element binding (CREB) protein during hypoxia in cerebral cortex of newborn piglets and the effect of nitric oxide synthase inhibition. Neuroscience, 115:985-91.

Mishra OP, Zubrow AB, Ashraf QM, et al. 2006. Nuclear Ca(++)-influx, $\mathrm{Ca}(++) /$ calmodulin-dependent protein kinase IV activity and CREB protein phosphorylation during post-hypoxic reoxygenation in neuronal nuclei of newborn piglets: the role of nitric oxide. Neurochem Res, 31:1463-71.

Mishra OP, Zubrow AB, Ashraf QM. 2004. Nitric oxide-mediated activation of extracellular signal-regulated kinase (ERK) and c-jun N-terminal kinase (JNK) during hypoxia in cerebral cortical nuclei of newborn piglets. Neuroscience, 123:179-86.
Miyake K, Ibaraki N. 2002. Prostaglandins and cystoid macular edema. Surv Ophthalmol, 47:S203-8.

Mizui T, Kinouchi H, Chan PH. 1992. Depletion of brain glutathione by buthionine sulfoximine enhances cerebral ischemic injury in rats. $\mathrm{Am}$ J Physiol, 262:H313-7.

Moncada S, Palmer RM, Higgs, EA. 1991. Nitric oxide: physiology, pathophysiology, and pharmacology. Pharmacol Rev, 43:109-42.

Muller A, Pietri S, Villain M, et al. 1997. Free radicals in rabbit retina under ocular hyperpressure and functional consequences. Exp Eye Res, 64:637-43.

Murata T, Nakagawa K, Khalil A, et al. 1996. The relation between expression of vascular endothelial growth factor and breakdown of the blood retinal barrier in diabetic rat retinas. Lab Invest, 74:819-25.

Nakajima W, Ishida A, Lange MS, et al. 2000. Apoptosis has a prolonged role in the neurodegeneration after hypoxic ischemia in the newborn rat. J Neurosci, 20:7994-8004.

Namura S, Zhu J, Fink K, et al. 1998. Activation and cleavage of caspase-3 in apoptosis induced by experimental cerebral ischemia. $J$ Neurosci, 18:3659-68.

Neufeld AH, Kawai S, Das S, et al. 2002. Loss of retinal ganglion cells following retinal ischemia: the role of inducible nitric oxide synthase, Exp Eye Re, 75:521-8.

Neufeld G, Cohen T, Gengrinovitch S, et al. 1999. Vascular endothelial growth factor (VEGF) and its receptors. FASEB J, 13:9-22.

Nguyen SM, Alexejun CN, Levin LA. 2003. Amplification of a reactive oxygen species signal in axotomized retinal ganglion cells. Antioxid Redox Signal, 5:629-34.

Nguyen T, Brunson D, Crespi CL, et al. 1992. DNA damage and mutation in human cells exposed to nitric oxide in vitro. Proc Natl Acad Sci US A, 89:3030-4.

Nicotera P, Orrenius S. 1998. The role of calcium in apoptosis. Cell Calcium, 23:173-80.

Noda M, Nakanishi H, Nabekura J, et al. 2000. AMPA-kainate subtypes of glutamate receptor in rat cerebral microglia. J Neurosci, 20:251-8.

Osborne NN, Casson RJ, Wood JP, et al. 2004. Retinal ischemia: mechanisms of damage and potential therapeutic strategies. Prog Retin Eye Res, 23:91-147.

Osborne NN, Chidlow G, Nash MS, et al. 1999. The potential of neuroprotection in glaucoma treatment. Curr Opin Ophthalmol, 10:82-92.

Pang IH, Wexler EM, Nawy S, et al. 1999. Protection by eliprodil against excitotoxicity in cultured retinal ganglion cells. Vis Sci, 40:1170-6.

Pin JP, Duvoisin R. 1995. The metabotropic glutamate receptors: structure and functions. Neuropharmacology, 34:1-26.

Prass K, Scharff A, Ruscher K, et al. 2003. Hypoxia-induced stroke tolerance in the mouse is mediated by erythropoietin. Stroke, 34:1981-6.

Proescholdt MA, Heiss JD, Walbridge S, et al. 1999. Vascular endothelial growth factor (VEGF) modulates vascular permeability and inflammation in rat brain. $J$ Neuropathol Exp Neurol, 58:613-27.

Proescholdt MA, Jacobson S, Tresser N, et al. 2002. Vascular endothelial growth factor is expressed in multiple sclerosis plaques and can induce inflammatory lesions in experimental allergic encephalomyelitis rats. J Neuropathol Exp Neurol, 61:914-25.

Pulera MR, Adams LM, Liu H, et al. 1998. Apoptosis in a neonatal rat model of cerebral hypoxia-ischemia. Stroke, 29:2622-30

Purtscher O. 1912. Angiopathia retinae traumatica: lymphorrhagien desaugengrundes. Graefes Arch Klin Exp Ophthalmol, 82:347-71.

Quigley HA, Nickells RW, Kerrigan LA, et al. 1995. Retinal ganglion cell death in experimental glaucoma and after axotomy occurs by apoptosis. Invest Ophthalmol Vis Sci, 36:774-86.

Quinn TP, Peters KG, De Vries C, et al. 1993. Fetal liver kinase 1 is a receptor for vascular endothelial growth factor and is selectively expressed in vascular endothelium. Proc Natl Acad Sci U S A, 90:7533-7.

Ratan RR, Murphy TH, Baraban JM. 1994. Oxidative stress induces apoptosis in embryonic cortical neurons. J Neurochem, 62:376-9.

Reichenbach A, Wurm A, Pannicke T, et al. 2007. Müller cells as players in retinal degeneration and edema. Graefes Arch Clin Exp Ophthalmol, 245:627-36. 
Renolleau S, Aggoun-Zouaoui D, Ben-Ari Y, et al. 1998. A model of transient unilateral focal ischemia with reperfusion in the P7 neonatal rat: morphological changes indicative of apoptosis. Stroke, 29:1454-60.

Rörig B, Grantyn R. 1993. Rat retinal ganglion cells express $\mathrm{Ca}(2+)-$ permeable non-NMDA glutamate receptors during the period of histogenetic cell death. Neurosci Lett, 153:32-6.

Salgo MG, Bermúdez E, Squadrito GL, et al. 1995. Peroxynitrite causes DNA damage and oxidation of thiols in rat thymocytes. Arch Biochem Biophys, 322:500-5.

Salt TE, Binns KE, 2000. Contributions of mGlu1 and mGlu5 receptors to interactions with N-methyl-D-aspartate receptor-mediated responses and nociceptive sensory responses of rat thalamic neurons. Neuroscience, 100:375-80.

Salvemini D, Wang Z, Stern M, et al. 1998. Peroxynitrite decomposition catalysts: therapeutics for peroxynitrite-mediated pathology. Proc Natl Acad Sci U S A, 95:2695-703.

Sattler R, Tymianski M, 2001. Molecular mechanisms of glutamate receptor-mediated excitotoxic neuronal cell death. Mol Neurobiol, 24(1-3):107-29.

Schoch HJ, Fischer S, Marti HH, 2002. Hypoxia-induced vascular endothelial growth factor expression causes vascular leakage in the brain. Brain, 125:2549-57.

Senger DR, Perruzzi CA, Feder J, et al. 1986. A highly conserved vascular permeability factor secreted by a variety of human and rodent tumor cell lines. Cancer Res, 46:5629-32.

Shelhamer JH, Volkman DJ, Parrillo JE, et al. 1985. Takayasu's arteritis and its therapy. Ann Intern Med, 103:121-6.

Shibuya M, Ito N, Claesson-Welsh L, 1999. Structure and function of vascular endothelial growth factor receptor-1 and -2. Curr Top Microbiol Immunol, 237:59-83.

Shimazaki K, Ishida A, Kawai N, 1994. Increase in bcl-2 oncoprotein and the tolerance to ischemia-induced neuronal death in the gerbil hippocampus. Neurosci Res, 20:95-9.

Siliprandi R, Canella R, Carmignoto G et al. 1992. N-methyl$\mathrm{D}$-aspartate-induced neurotoxicity in the adult rat retina, Visual Neurosci, 8:567-73.

Sohn S, Kim EY, Gwag BJ. 1998. Glutamate neurotoxicity in mouse cortical neurons: atypical necrosis with DNA ladders and chromatin condensation. Neurosci Lett, 240:1-4.

Southam E, Garthwaite J. 1993. The nitric oxide-cyclic GMP signalling pathway in rat brain. Neuropharmacology, 32:1267-77.

St Clair EG, Anderson SJ, Oltvai ZN. 1997. Bcl-2 counters apoptosis by Bax heterodimerization-dependent and -independent mechanisms in the T-cell lineage. J Biol Chem, 272:29347-55.

Stein I, Neeman M, Shweiki D, et al. 1995. Stabilization of vascular endothelial growth factor mRNA by hypoxia and hypoglycemia and coregulation with other ischemia-induced genes. Mol Cell Biol, 15:5363-8.

Sucher NJ, Aizenman E, Lipton SA. 1991. NMDA antagonists prevent kainate neurotoxicity in rat retinal ganglion cells. J Neurosci, 11:966-71.

Sucher NJ, Lipton SA, Dreyer EB. 1997. Molecular basis of glutamate toxicity in retinal ganglion cells. Vision Res, 37:3483-93.

Sucher NJ, Wong LA, Lipton SA. 1990. Redox modulation of NMDA receptor-mediated $\mathrm{Ca} 2+$ flux in mammalian central neurons. Neuroreport, 1:29-32

Szabo ME, Droy-Lefaix MT, Doly M. 1997. Direct measurement of free radicals in ischemic/reperfused diabetic rat retina. Clin Neurosci, 4:240-5.

Szaflarski J, Burtrum D, Silverstein FS. 1995. Cerebral hypoxia-ischemia stimulates cytokine gene expression in perinatal rats. Stroke, 26:1093-100.

Tan S, Sagara Y, Liu Y, et al. 1998. The regulation of reactive oxygen species production during programmed cell death. $J$ Cell Biol, 141:1423-32.

Tezel G, Wax MB. 2004. The immune system and glaucoma. Curr Opin Ophthalmol, 15:80-4.

Tezel G, Yang X. 2004. Caspase-independent component of retinal ganglion cell death, in vitro. Invest Ophthalmol Vis Sci, 45:4049-59.
Tielsch JM, Katz J, Sommer A, et al. 1995. Hypertension, perfusion pressure, and primary open-angle glaucoma. A population-based assessment. Arch Ophthalmol, 113:216-21.

Tinjust D, Kergoat H, Lovasik JV. 2002. Neuroretinal function during mild systemic hypoxia. Aviat Space Environ Med, 73:1189-94.

Toda N, Nakanishi-Toda M, 2007. Nitric oxide: ocular blood flow, glaucoma, and diabetic retinopathy. Prog Retin Eye Res, 26:205-38.

Tolentino MJ, Miller JW, Gragoudas ES, et al. 1996. Intravitreous injections of vascular endothelial growth factor produce retinal ischemia and microangiopathy in an adult primate. Ophthalmology, 103:1820-128.

Tso MOM. 1982. Pathology of cystoid macular oedema. Ophthalmology, 89:902- 15

van Dam PS. 2002. Oxidative stress and diabetic neuropathy: pathophysiological mechanisms and treatment perspectives. Diabetes Metab Res Rev, 18:176-84.

Wang J, Beekhuizen H, van Furth R. 1994. Surface molecules involved in the adherence of recombinant interferon-gamma (rIFN-gamma)stimulated human monocytes to vascular endothelial cells. Clin Exp Immunol, 95:263-9.

Wang Q, Tang XN, Yenari MA. 2007. The inflammatory response in stroke. J Neuroimmunol, 184:53-68.

Wang X, Niwa M, Hara A, et al. 2002. Neuronal degradation in mouse retina after a transient ischemia and protective effect of hypothermia. Neurol Res, 24:730-5.

Wax MB, Tezel G. 2002. Neurobiology of glaucomatous optic neuropathy: diverse cellular events in neurodegeneration and neuroprotection. $\mathrm{Mol}$ Neurobiol, 26:45-55.

Werns SW, Shea MJ, Lucchesi BR . 1985. Free radicals in ischemic myocardial injury. J Free Radic Biol Med, 1:103-10.

Wong D, Dorovini-Zis K. 1992. Upregulation of intercellular adhesion molecule-1 (ICAM-1) expression in primary cultures of human brain microvessel endothelial cells by cytokines and lipopolysaccharide, J Neuroimmunol, 39:11-21.

Wong ML, Bongiorno PB, al-Shekhlee A, et al. 1996. IL-1 beta, IL-1 receptor type I and iNOS gene expression in rat brain vasculature and perivascular areas. Neuroreport, 7:2445-8.

Yanoff M, Fine BS, Brucker AJ, et al. 1984. Pathology of human cystoid macular oedema. Surv Ophthalmol, 28 (Suppl):505-11.

Yoshida S, Yoshida A, Ishibashi T. 2004. Induction of IL-8, MCP-1, and bFGF by TNF-alpha in retinal glial cells: implications for retinal neovascularization during post-ischemic inflammation. Graefes Arch Clin Exp Ophthalmol, 242:409-13.

Yue X, Mehmet H, Penrice J, et al. 1997. Apoptosis and necrosis in the newborn piglet brain following transient cerebral hypoxia-ischaemia Neuropathol Appl Neurobiol, 23:16-25.

Zhang ZG, Zhang L, Jiang Q, et al. 2000. VEGF enhances angiogenesis and promotes blood-brain barrier leakage in the ischemic brain. J Clin Invest, 106:829-38.

Zhang ZG, Zhang L, Tsang W, et al. 2002. Correlation of VEGF and angiopoietin expression with disruption of blood-brain barrier and angiogenesis after focal cerebral ischemia. J Cereb Blood Flow Metab, 22:379-92.

Zhang, RL, Chopp, M, Chen, H, et al. 1994. Temporal profile of ischemic tissue damage, neutrophil response, and vascular plugging following permanent and transient $(2 \mathrm{H})$ middle cerebral artery occlusion in the rat. J Neurol Sci, 125:3-10.

Zheng L, Gong B, Hatala DA, et al. 2007. Retinal ischemia and reperfusion causes capillary degeneration: similarities to diabetes. Invest Ophthalmol Vis Sci, 48:361-7.

Zubrow AB, Delivoria-Papadopoulos M, Ashraf QM, et al. 2002a. Nitric oxide-mediated $\mathrm{Ca} 2+/$ calmodulin-dependent protein kinase IV activity during hypoxia in neuronal nuclei from newborn piglets. Neurosci Lett, 335:5-8.

Zubrow AB, Delivoria-Papadopoulosm M, Ashrafm QM, et al. 2002b. Nitric oxide-mediated expression of Bax protein and DNA fragmentation during hypoxia in neuronal nuclei from newborn piglets. Brain Res, 95:60-7. 
